\title{
Evidence of Shock Metamorphism Effects in Allochthonous Breccia Deposits from the Colônia Crater, São Paulo, Brazil
}

\author{
Victor F. Velázquez ${ }^{1}$, Claudio Riccomini ${ }^{2}$, José M. Azevedo Sobrinho ${ }^{3}$, Mikhaela A. J. S. Pletsch ${ }^{1}$, \\ Alethéa E. Martins Sallun ${ }^{3}$, William Sallun Filho ${ }^{3}$, Jorge Hachiro ${ }^{2}$ \\ ${ }^{1}$ Escola de Artes, Ciências e Humanidades, Universidade de São Paulo, São Paulo, Brasil \\ ${ }^{2}$ Instituto de Geociências, Universidade de São Paulo, São Paulo, Brasil \\ ${ }^{3}$ Instituto Geológico, Secretaria do Meio Ambiente, São Paulo, Brasil \\ Email: vvf@usp.br
}

Received October 16, 2012; revised November 17, 2012; accepted December 19, 2012

\begin{abstract}
The $3.6 \mathrm{~km}$-diameter Colônia impact crater, centred at $23^{\circ} 52^{\prime} 03^{\prime \prime} \mathrm{S}$ and $46^{\circ} 42^{\prime} 27^{\prime \prime} \mathrm{W}$, lies $40 \mathrm{~km}$ to the south-west of the São Paulo city. The structure was formed on the crystalline basement rocks and displays a bowl-shaped with steeper slope near the top that decreases gently toward the centre of the crater. Over recent years were drilled two boreholes inside the crater, which reached a maximum depth of $142 \mathrm{~m}$ and $197 \mathrm{~m}$. Geological profile suggests four different lithological associations: 1) unshocked crystalline basement rocks (197 - $140 \mathrm{~m}) ; 2$ ) fractured/brecciated basement rocks (140 - $110 \mathrm{~m})$; 3) polymictic allochthonous breccia deposits (110 - $40 \mathrm{~m})$; and 4) post-impact deposits (40 - $0 \mathrm{~m})$. Petrographic characterisation of the polymictic allochthonous breccia reveals a series of distinctive shock-metamorphic features, including, among others, planar deformation features in quartz, feldspar and mica, ballen silica, granular texture in zircon and melt-bearing impact rocks. The occurrence of melt particles and very high-pressure phase transformation in suevite breccia suggest a shock pressure regime higher than $60 \mathrm{GPa}$.
\end{abstract}

Keywords: Colônia Crater; Polymictic Allochthonous Breccia; Shock Metamorphism Effects

\section{Introduction}

The proposal of impact cratering as a geological process was severely criticised by some scientists at the beginning. Only in the sixties, and particularly in the nineties, when fragments of the comet Shoemaker-Levy 9 collided colossally on the dense atmosphere of Jupiter [1], the studies on the interplanetary collisions and the formation process of impact craters were heightening gradually. Since that time, the field of impact geology has increased substantially, and exhaustive investigations have been conducted to determine the physical transformations caused by the hypervelocity impact [2].

According to PASSC [3], 183 individual craters have already been confirmed worldwide. However, only six structures were heretofore catalogued in Brazil. This fact is due in large part because the Brazilian territory has a complex geological history with several episodes of compressional and extensional deformation, multiple igneous intrusions and volcanic eruptions [4-6]. Likewise, an Atlantic tropical climate prevails over the coastal region that heightens the processes of weathering and erosion. In such geological settings, the terrestrial crust material is continuously being reworked and the likelihoods of preserving an impact structure are remote.

The origin of the Colônia Crater by extraterrestrial body impact was firstly proposed by Koller et al. [7]. In order to better characterise the structure, several studies were later conducted by Crósta $[8,9]$ and Riccomini et al. $[10,11]$, suggesting that the circular depression of Colônia could have been generated by an extraterrestrial impact. Subsequently, geophysical studies were carried out by Mota and Flexor [12], Masero and Fontes [13] and Neves [14], providing the first models of impact cratering. Although no direct evidence has been found (shatter cone, PDFs in minerals and diaplectic glass), an integrated analysis of the geological and geophysical data available in the literature led Riccomini et al. $[15,16]$ to postulate a meteorite impact origin for the Colônia structure.

Individual circular structure is usually quoted as an important record of hypervelocity impact cratering [17]. Nevertheless, morphological features are only a preliminary indication of a possible impact crater, being insufficient to discern their origin of other geological processes 
$[18,19]$. At the impact place, the kinetic energy is transformed into high-pressure shock waves that propagate at a supersonic velocity [2]. Under these extreme physical conditions, rocks and minerals are strongly modified and a wide variety of unusual microstructures of irreversible changes is formed [20-23]. According to Langenhorst [24] and French and Koeberl [25], marks of shock waves in minerals are convincing proofs and, often, the last distinctive register of impact cratering. In this paper is reported, for the first time, a set of representative optical features of shock-inducted microdeformations in rock fragments and mineral clasts that were preserved in allochthonous breccia deposits from the Colônia Crater.

\section{Geological Setting}

The Colônia Crater is located at $40 \mathrm{~km}$ of the São Paulo city, centred at $23^{\circ} 52^{\prime} 27^{\prime \prime} \mathrm{S}$ and $46^{\circ} 42^{\prime} 36^{\prime \prime} \mathrm{W}$, in the Parelheiros district. The name is attributed to the smalltown of Colônia placed near the rim NE of the structure. This ring-like depression, with $3.6 \mathrm{~km}$ rim-to-rim diameter, represents the most outstanding geomorphological feature in the region [11]. On satellite images, it is possible noting a circular outline formed by several flattened hills that configure a smooth bowl shape, with gentle slope of the inner walls and a difference of $120 \mathrm{~m}$ relief between the rim and the crater floor (Figure 1).

The Colônia Crater is a simple relatively small structure that was formed on a complex orogenic zone, known in the literature as Ribeira Fold Belt [26]. Three major lithostratigraphic units may be distinguished in the region (Figure 2): 1) the Precambrian crystalline basement; 2) the Tertiary sediments; and 3) the Quaternary deposits [27]. The basement rocks form part of the Embu Complex [28], which is largely composed of mica schist, gneiss, quartzite, migmatite, diorite and quartz diorite $[27,29]$. In the south and south-eastern rims of the crater, the crystalline basement is partially covered by sedimenttary deposits. According to Riccomini et al. [30], these

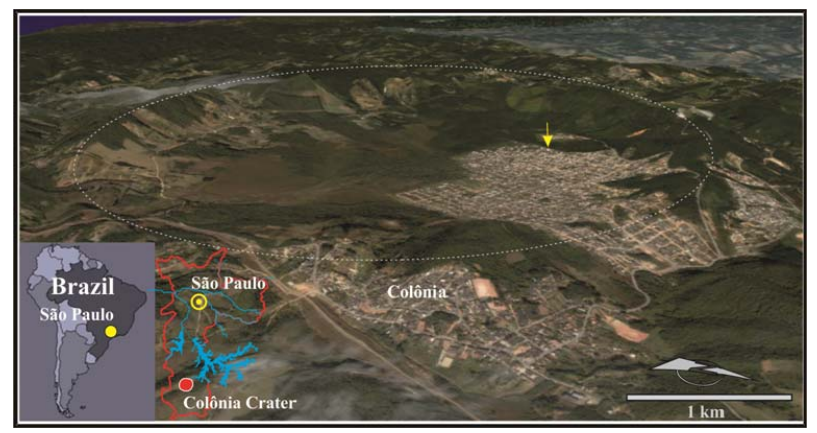

Figure 1. Morphological aspect of the Colônia impact crater. The dotted circle delineates the crater rim, and the yellow arrow indicates the place of the boreholes. Inset: Schematic map location.

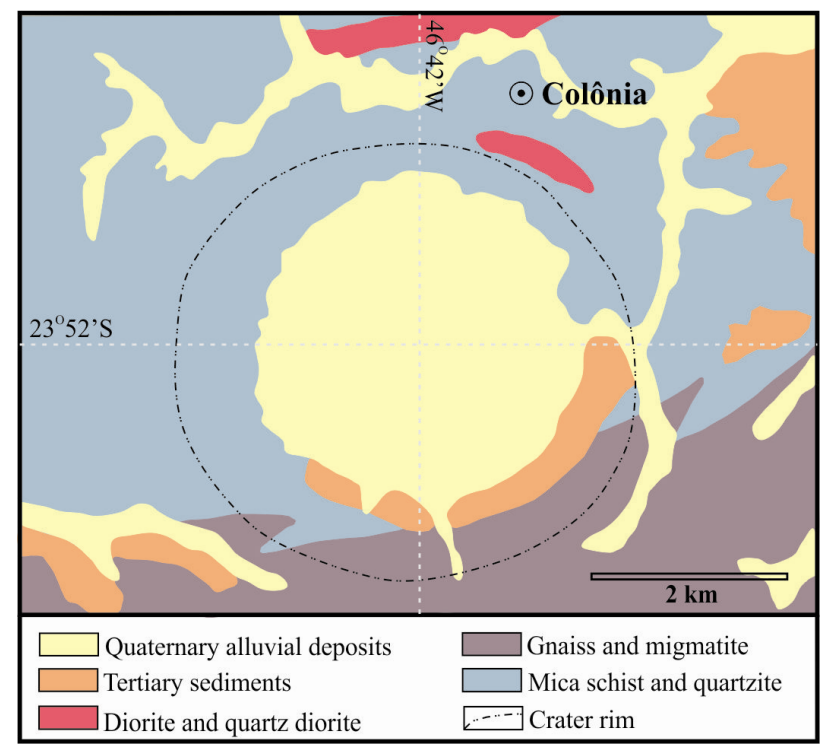

Figure 2. Simplified geological map of the Colônia impact crater (extracted of Riccomoni et al. [31]).

siliciclastic deposits of Palaeogene age can be correlated with the Resende Formation of the São Paulo Basin.

The youngest sediments are those of Quaternary age which extends up to the present. This unit is widely distributed within the crater and consists of a succession of alternate layers that comprise chiefly psammitic and organo-pelitic sediments.

Excepting the alluvial deposits, several superimposed structures occur in the crystalline basement and sedimentary rocks. The deformations include a wide range of faults and fractures that reveal a pattern of unusual orientation, a significant variation of the palaeostress field and fluid's percolation along the planes.

\section{The Borehole Samples}

Over recent years, two boreholes were drilled inside the crater for groundwater exploration. The wells have depths of 142 and $197 \mathrm{~m}$, and, in both cases, the drillings crossed a thick sequence of chaotic sedimentary deposits reaching up to the crystalline basement rocks. During the drilling step were collected $500 \mathrm{~g}$ of crushed rock samples to each $2 \mathrm{~m}$ depths. Despite the samples were not obtained from continuous coring drill, the material reveals a geological profile consisting of, at least, four different lithological associations (Figure 3): 1) unshocked crystalline basement rocks (197 - $140 \mathrm{~m}$ ), formed mostly by fragments of mica schist, gneiss, quartzite and granite; 2) fractured/brecciated basement rocks (140 - $110 \mathrm{~m})$, similar to the former unit, although with a remarkable deformation. The brittle and ductile structures are much more intense and pervasive than those exposed along the outer margin of the crater; 3) allochthonous crater-fill deposits $(110-40 \mathrm{~m})$, include a complex mixture of 
lithic fragments and mineral clasts derived from crystalline basement rocks and, more rarely, of older sedimentary rocks. Such materials show different stages of shocked metamorphism, from intensely fractured mineral clasts, PDF in single crystal up to impact-melt rocks; and 4) post-impact deposits $(40-0 \mathrm{~m})$ consist of fine- to coarse-grained siliciclastic sediments, very-poorly sorted, with some intercalations of organo-pelitic materials. The terrigenous sediments include, in order of abundance, disaggregated clasts of quartz, K-feldspar, mica, tourmaline and clay minerals. Other smaller constituents are zircon, epidote, biotite, corundum, plagioclase, apatite, anatase, and rutile, as well as lithic fragments of igneous and metamorphic rocks.

The precise contact between the lower section of the crater-fill deposits and the crystalline basement rocks is still poorly known. Geophysical data carried out by Neves [14] suggest a thickness of $450 \mathrm{~m}$. However, recently research published by Riccomini et al. [31] points to a much smaller thickness of roughly $275 \mathrm{~m}$.

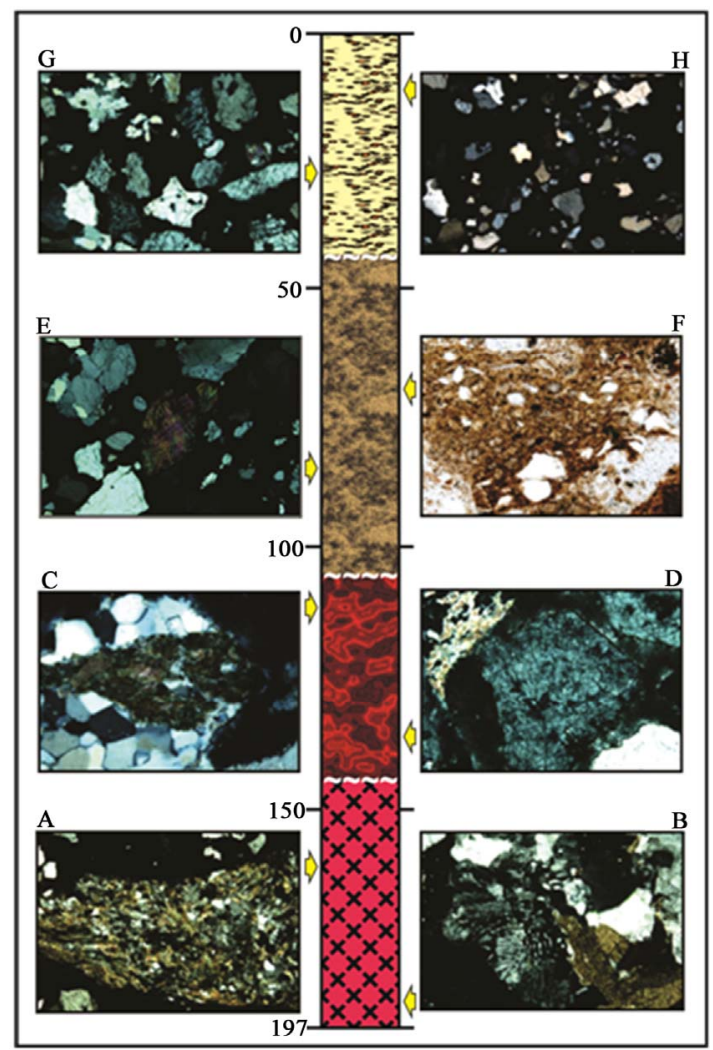

Figure 3. Schematic geological profile of the Colônia impact crater (depth in metres). (A and B) Mica schist and granite from the basement rocks; (C and D) Quartzite, mica schist and granite from the fractured/brecciated basement rocks; $(E$ and $F$ ) Lithic and suevite breccias from the polymictic allochthonous breccia; ( $G$ and $H$ ) Heterogeneous mixture of lithic fragments and mineral clasts, mainly quartz and feldspar, from the post-impact deposits. The diacritical marks indicate the contacts inferred.

\section{Shock-Induced Microdeformation Features}

A careful petrographic examination was performed on a set of 60 samples selected from different depth levels, which allowed identifying a series of shock metamorphic effects in lithic fragments and mineral clasts.

\subsection{Polymictic Allochthonous Breccia}

The term "polymictic allochthonous breccia" is used here following the nomenclature proposed by Stöffler and Grieve [32] to designate a complex mixture of angular lithic fragments, mineral clasts and splinter of melt-bearing rocks of the lower section of the crater-fill deposits. Except for a few fragments of sedimentary origin, the polymictic breccia is mostly constituted of materials that were derived from a target of crystalline basement rocks. The angular lithic fragments range in size from $50 \mathrm{~mm}$ to $5 \mathrm{~cm}$ and present a wide lithological variation, containing mica schist, gneiss, quartzite and granitoid rocks. The mineral clasts are broadly diversified in size, varying from $0.05 \mathrm{~mm}$ up to $2 \mathrm{~cm}$, and represent a heterogeneous assembly of quartz, k-feldspar, mica, tourmaline and other minor components such as opaque, zircon, epidote, corundum, plagioclase, apatite, anatase, and rutile. All of these materials are immersed within a fine-grained groundmass of dark yellowish-red colour constituted of tiny grains of quartz, microlites of k-feldspar, disseminated Fe-oxide/hydroxide, opaques, and phyllosilicates (Figure 4).
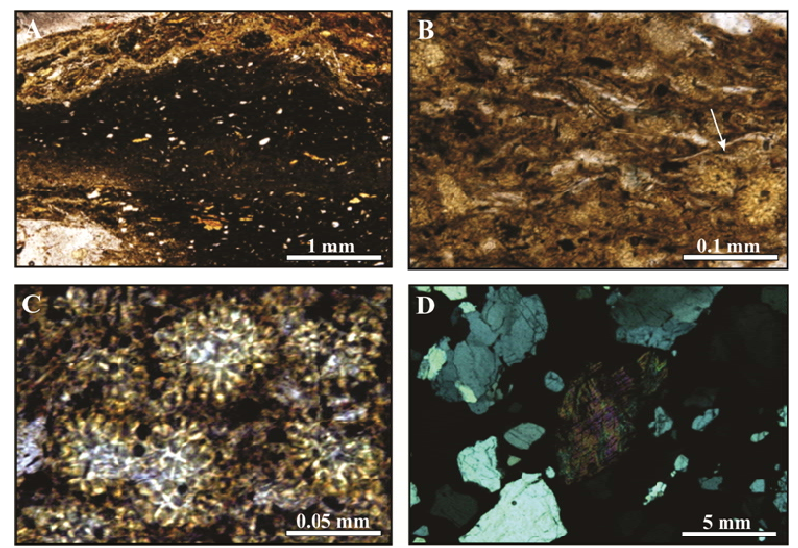

Figure 4. Shock-metamorphosed target rocks. (A) Suevite breccia showing a heterogeneous mixture of angular mineral clasts in fine groundmass of yellow-brownish colour, with multiple layers and flow-banded texture; (B) Suevite breccia exhibing a aphanitic groundmass, partly glassy to distinctly crystalline, with flow stretching, and several spherical glass globules; (C) Higher magnification of the spherical globules with filling of silica glass in droplets-shaped; (D) Poorly sorted lithic breccia containing mineral clasts, mainly quartz and feldspar, and a few lithic fragments of granitic composition. Excepting the image D, all were taken with parallel nicols. 
The polymictic breccia also contains variable amounts ( $<10$ to $>30$ vol\%) of partially molten rocks and minerals initially transformed into glass. In this case, the aphanitic groundmass, partially devitrified and with fluidal texture markedly contorted, is composed of several spherical globules filled with silica glass in droplets-shaped. According to French [2] and Stöffler and Grieve [32], the presence of melt component in allochthonous crater-fill deposits is one of the important diagnostic features for classifying suevite breccia.

\subsection{Mineral Clasts}

There is a remarkable predominance of metamorphic and igneous basement rocks on the provenance of the mineral clasts. The assembly is mostly composed of quartz, kfeldspar, mica and tourmaline. Other minor constituents include opaques, plagioclase, zircon, epidote, corundum, apatite, anatase, and rutile. It is worth mentioning that the presence of shock metamorphism features was only observed in a few grains of those minerals, and the following descriptions are presented without establishing any order more rigid concerning the degree of deformation of the minerals.

\subsubsection{Quartz}

The quartz grains ranging in size from 0.10 to $30 \mathrm{~mm}$ and roughly $40 \%$ of the population displays commonly some shock-induced microdeformations, with emphasis for an intense intragranular microfracture, grain mosaicism, planar microstructures, planar deformation features and, more rarely, ballen texture (Figure 5). The intragranular microfractures are formed by several short planar fractures with different orientations, between 5 to 25 $\mu \mathrm{m}$ wide, occasionally lengthy and curved. Smaller angular fragments of quartz within a single grain, with different crystallographic orientation and low birefringence, are common.

Mosaic extinction pattern occurs in some grains, which is noticeably different from the broad, sweeping, undulatory extinction. Grain mosaicism is characterised by the marked reduction of birefringence, subdomains of crystal misorientation, blocky and patchy extinction.

Planar microstructures in quartz grains are similar to those that occur in other confirmed impact structures, in particular, Meteor Crater, Arizona [33]. The open microfractures, with flat to curviplanar planes, occur in parallel sets of multiple planar microcraks arranged to distinct crystallographic orientations.

Planar deformation features are less common. In thin section, the planes appear as open fractures, but they are often filled with tiny inclusions of opaque material. The lamellae form 2 - 4 sets of planes parallel with different orientations, and individual lamellae are typically 0.05 $1.5 \mathrm{~mm}$ long, 3 - $10 \mu \mathrm{m}$ wide and are closely spaced.
Ballen-bearing quartz was identified in lithic fragments of granitoid composition from the polymictic breccia deposits. The outlines of the ballen loops can take many shapes, but are most usually oval or round and bear a very close resemblance to those described by Langenhorst and Deutsch [34] as a cauliflower-like fracture pattern. The ballen size is rather diversified and consists of a haphazard assortment of loops, resembling a cluster of grapes in appearance. In plane polarised light, individual ballen displays heterogeneous extinction with different optical orientation, suggesting intraballen recrystallisation (cf. Ferrière et al. [35]).

\subsubsection{Potassium Feldspar}

Microcline and potassium-rich orthoclase, more rarely plagioclase, are the most common constituents of the crystalline basement rocks. These minerals occur as anhedral single crystal with irregular borders, showing enormous variation in size $(0.12-25 \mathrm{~mm})$. In general, the grains display one or more distinctive microdeformation features, including: 1) intense microfractures; 2) irregular optical extinction; 3) planar fracture and 4) planar deformation features. Although more rarely, it is also possible identifying the effect of thermal transformation on plagioclase grains (Figure 6).

Planar fractures appear typically forming sets of parallel open microfractures and they may be distinguished into two specific morphological classes. The first set includes several pervasive microcracks, with 20 to $30 \mu \mathrm{m}$ wide and large spacing. An anomalous birefringence is noticeable alongside the subplanar microdeformations. The second set comprises many planar thin lamellae, typically on the order of micrometres wide, much shorter and less spaced than the former.

Planar deformation features (PDFs) are very narrow lamellae, with regularly spaced intervals, arranged in parallel sets, showing two or more distinctive orientations. The lamellae are usually about 3 to $15 \mu \mathrm{m}$ wide, welldefined and not extend through the entire grain. A common feature of those lamellae is the low birefringence in comparison with the host crystal. Another peculiar feature of shock metamorphism effects takes place as irregular extinction, anomalous birefringence, curvilinear microcracks and planar deformation, which are very similar to those documented by Nagy et al. [36] in Kfeldspar from Bosumtwi impact crater, Ghana.

Plagioclase displays only partial thermal transformation. The mineral still preserves the original features, but contains abundant irregular exsolved phase with marked reduction of birefringence.

\subsubsection{Mica}

The occurrence of mica, both muscovite and biotite, as mineral clasts is relatively common. The grain sizes of a 

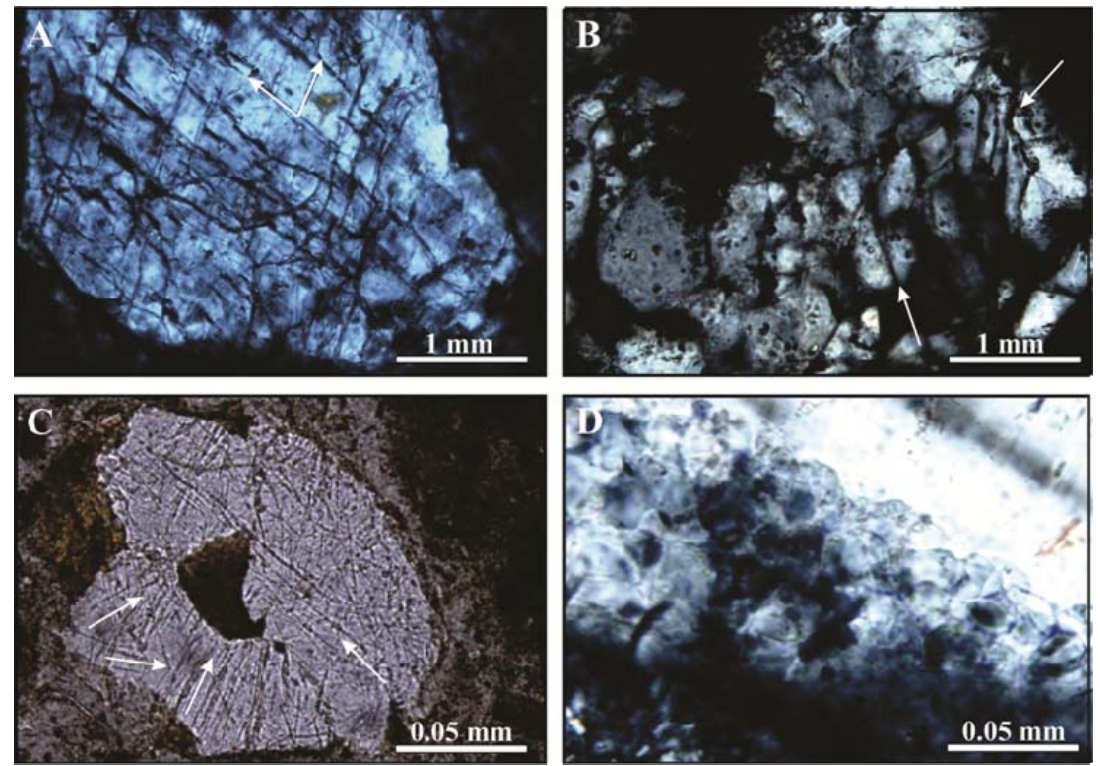

Figure 5. Shock metamorphism effects in quartz grains. (A) The intersection of two sets of intragranular microfractures configures a perfect rhombohedral cleavage, along which is possible noting several displacements; (B) Anomalous extinction and intense irregular fractures; (C) A possible recrystallised grain exhibiting several sets of partially decorated PDFs; (D) Ballen quartz with remarkable heterogeneous extinction. Excepting the image $C$, all were taken with crossed nicols.
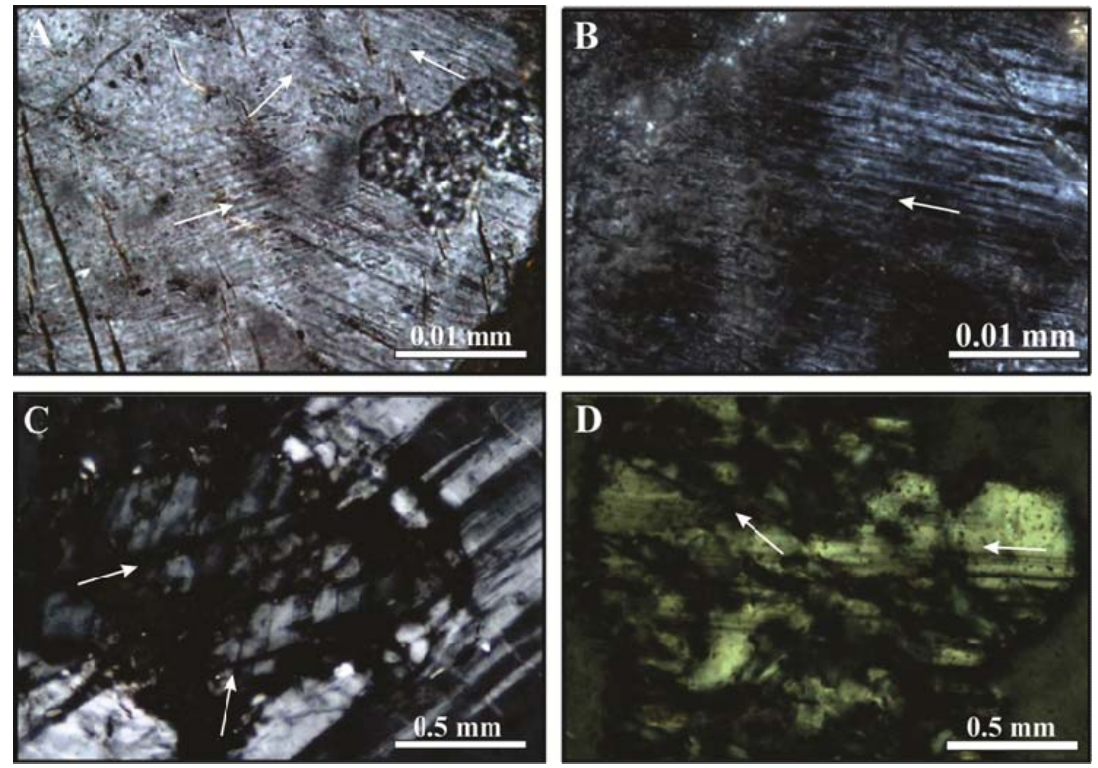

Figure 6. Shock metamorphism effects in feldspar grains. (A) Orthoclase feldspar showing three sets of PDFs with regular spacing; (B) Orthoclase feldspar with a single set of short, narrow, closely spaced planar features (roughly E-W); (C) Microcline feldspar with two sets of PFs, evidencing intense deformation and rotation of the twinning planes of albite and pericline laws; (D) Plagioclase with partial transformation preserving the twinning planes of albite law (E-W). Note that the platelets of the exsolved phase, with low birefringence, are obliquely arranged regarding to twinning planes. The imagines were taken with crossed nicols.

single crystal may vary from minuscule flakes $(0.12 \mathrm{~mm})$ up to flexible plates with about $2 \mathrm{~cm}$. The kink-bands are the most frequent microdeformation in individual mica, and, more rarely, planar deformation elements (Figure 7). The kink-like structure appears as lens-shaped showing high asymmetry, irregular spacing, and the borders are often curved. Some mica grains present complex deformations and the dislocation of the bands is nearly always parallel to the basal plane. In contrast to the kink-bands, planar elements display an appearance of very fine lamellae, arranged in parallel sets and closely spaced, analogous to those described by Schneider [37]. The 
most prominent set of planar structure was registered in section orthogonal to the basal plane. In this orientation, the biotite displays an anomalous birefringence and an incipient melting in different parts of the border. Along the fine lamellae, the birefringence is completely reduced.

\subsubsection{Zircon}

The zircon crystals have a well-preserved external morphology, showing a short prismatic habit with pyramidal termination and without any evidence of overgrown. In sections parallel to the c-axis, the grain sizes may range from $0.15-2 \mathrm{~mm}$. As a result of shock metamorphism, the crystalline structure of some grains was rearranged, as suggested by the non-uniform undulatory extinction, anomalous birefringence, planar fractures and granular texture along the border (Figure 7). These optical characteristics are extremely unusual in igneous and metamorphic zircons, and their occurrences have been specifically reported as a particular feature of shocked zircons from hypervelocity impact environments (cf. Reimold et al. [38], Wittmann et al. [39], Timms et al. [40]).

\section{Discussion and Conclusion}

The Colônia impact crater has a simple bowl-shaped morphology, with circular topographic expression, gravimetric anomaly and magnetometric signature. The crater was mostly excavated on crystalline basement rocks. However, the presence of a few rounded granules of sedimentary origin in the polymictic allochthonous brec- cia suggests that a thin sedimentary layer would have partially covered the crystalline basement before the impact.

The characterisation of the lithological association from the boreholes samples allowed establishing a schematic geological cross-section with four different units: 1) pre-impact target-rock, composed of unshocked metamorphic and igneous basement rocks; 2) fractured/brecciated crystalline basement rocks; 3) polymictic allochthonous breccia deposits, composed of angular clasts derived from different crystalline basement rocks; 4) post-impact deposits, which represent a series of thin layers of heterogeneous unconsolidated sediments, resulting from the erosion of the underlying material that composes the uplifted crater rim.

Based on petrographic characterisation, two distinct breccia types were identified in the allochthonous breccia deposits: lithic and suevite breccias. Although both types of breccia are enough similar in its main lithological constituents, formed by a wide variety of rock fragments and mineral clasts that were derived of different target basement rocks, the suevite breccia is constituted of many lithic fragments partially melted, and mineral clasts devitrified immersed within a hyalocrystalline groundmass.

A large variety of microdeformation features was documented in individual mineral clasts. Anomalous refractive index, marked reduction of birefringence, grain mosaicism, planar fractures (PFs) and planar deformation features (PDFs) are most commonly found in quartz and
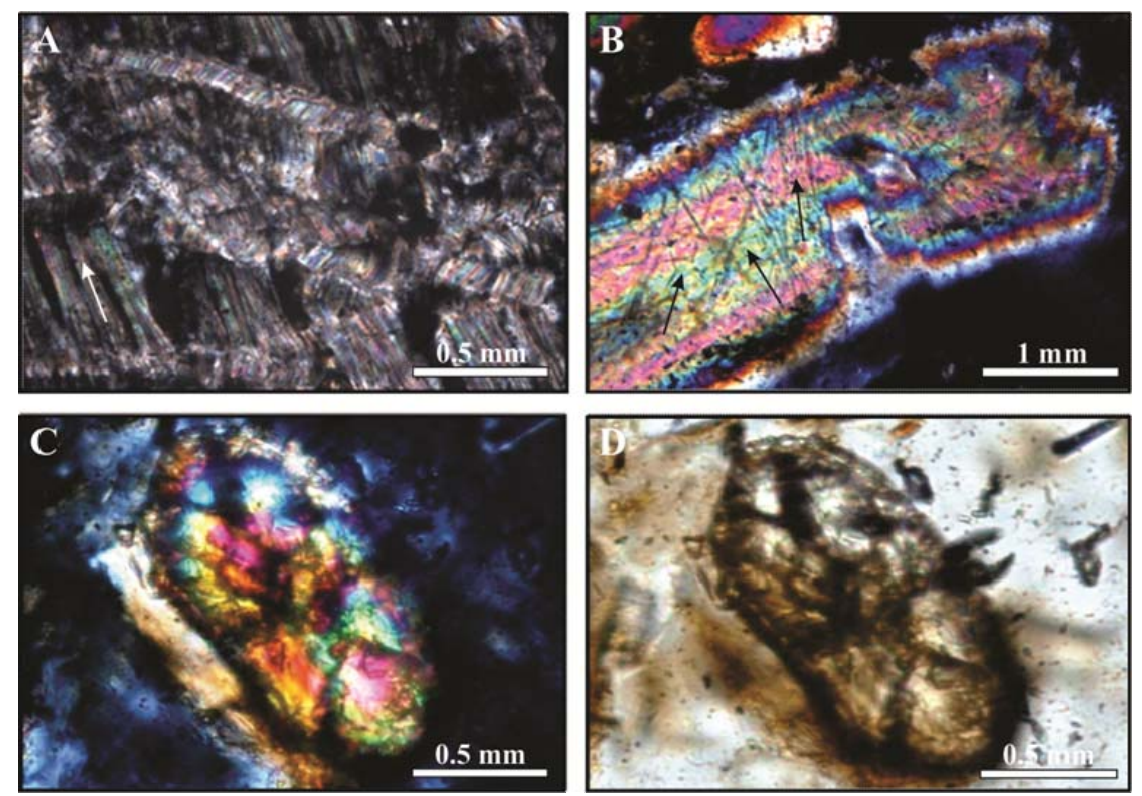

Figure 7. Shock metamorphism effects in mica and zircon minerals. (A) Complex kink bands deformation in muscovite. The arrow indicates the preferential direction of the cleavage plane; (B) Biotite showing three main sets of PDFs. Incipient opaquisation is noticeable in parts of the border; (C and D) A single crystal zircon, crossed and parallel nicols, with remarkable evidence of very high-pressure phase transformation. 
feldspar. In more strongly shocked specimens, ballen quartz and partial thermal transformation of k-feldspar/ plagioclase were also identified. Other important shockinduced deformations include kink bands deformation, incipient PDFs and partial melting in mica. Evidence of very high-pressure phase transformation was observed in single zircon crystal, showing a conspicuous development of granular texture along the border.

Field observations and petrographical descriptions are integrated with the data given in Stöffler [22] and Stöffler et al. [41] in order to estimate the progressive stages of shock metamorphism conditions. There is a strong correlation between the lithological domain of the regional geology, the pre-impact target rocks and the lithic components of the polymictic allochthonous breccia. On the basis of this evidence, and considering that the current rim has a diameter of $3.6 \mathrm{~km}$ and circumscribes thoroughly the allochthonous breccia deposits, it is reasonable to assume that the several types of microdeformations documented in silicate minerals represent different stages of shock metamorphism effects (Table 1). The range of shock pressures is relatively wide compared with the size of the structure, and the occurrence of melt particles is seemingly inferior regarding to other impact craters with similar geological setting (cf. PASSC [3]: Kgagodi, Ouarkziz, Zeleny Gai, Brent, Flynn Creek, Steinheim). This particular condition has probably been caused by the heterogeneous mixture of unshock and shock materials that were deposited during the stages of the crater-forming process. However, the maximum shock pressure, estimated from the presence of melt particle in suevite breccia and granular texture in zircon, is consistent with other well-characterised and documented shock barometers, in particular, with those proposed by Stöffler [42,43], Grieve et al. [44] and Leroux et al. [45].

Table 1. Shock metamorphism conditions for the Colônia impact crater. Pressure data and progressive stages of shock metamorphism are based on natural and experimental data given in Stöffler [22] and Stöffler et al. [41].

\begin{tabular}{|c|c|c|c|}
\hline Mineral & Shock Effects & $\begin{array}{l}\text { Shock Pressure } \\
\text { (GPa) }\end{array}$ & Shock Stage \\
\hline Quartz & $\begin{array}{l}\text { Intense fracturing, PFs, } \\
\text { PDFs, ballen texture }\end{array}$ & $5-45$ & 0 - III \\
\hline Feldspar & $\begin{array}{l}\text { Twinning lamellae } \\
\text { rotation, PFs, PDFs, } \\
\text { partial melting }\end{array}$ & $10-45$ & I - III \\
\hline Mica & $\begin{array}{l}\text { Kink bands, PDFs, } \\
\text { partial melting }\end{array}$ & $5-35$ & 0 - II \\
\hline Zircon & $\begin{array}{l}\text { Undulatory extinction, } \\
\text { granular texture }\end{array}$ & $45-60$ & IV \\
\hline
\end{tabular}

Another aspect that deserves a special mention is the significant thickness of the crater-fill deposits, estimated to be about $275 \mathrm{~m}$ by Riccomini et al. [31]. This sequence provides an extraordinary opportunity for a detailed research on the recent sedimentation history in the extreme south-eastern of Brazil. Preliminary studies driven by Ledru et al. $[46,47]$ on samples collected from the shallow drill core of the upper part of the section reveal important events of paleoclimatical changes that have happened along the last 100,000 years, which may be extended to more than 3 million years. In a particular way, the Colônia impact crater is a relevant natural heritage, inexhaustible source for a geological, paleoclimatical and paleoecological reconstruction [48,49].

As previously suggested by Velázquez et al. [50,51], further researches on the Colônia impact crater are necessary to establish 1) the thickness and distribution of volume melt-bearing breccia; 2) the presence or absence high-pressure silica polymorphs (coesite or stishovite); 3 ) the impact age by isotopic dating from impact-melt rocks; and 4) the composition of extraterrestrial components in impact rocks by specific geochemical analysis. Within this perspective, it is important emphasising that a new borehole was concluded the last year and, in order to elucidate some of the points mentioned above, several studies are currently in progress on the samples that were collected.

\section{Acknowledgements}

We are particularly grateful to Sebastião Carmo Silva for his excellent technical assistance during sample collection and to the Basic Sanitation Company of the State of São Paulo (SABESP) by the supplying the samples. C. Riccomini, A. E. M. Sallun and W. Sallun Filho are researchers with Productivity Grants of CNPq, Brazil. We would like to register our sincere gratitude to the anonymous referees who substantially improved the quality of the manuscript. This study has been supported by the FAPESP foundation, Proc. No. 2006/59046-6, 2011/ 50987-0 and 2012/50042-9.

\section{REFERENCES}

[1] T. J. Ahrens, T. Takata, J. D. O’Keefe and G. S. Orton, "Impact of Comet Shoemaker-Levy 9 on Jupiter," Geophysical Research Letters, Vol. 21, No. 21, 1994, pp. 1087-1090. doi:10.1029/94GL01325

[2] B. M. French, "Traces of Catastrophe: A Handbook of Shock-Metamorphic Effects in Terrestrial Meteorite Impact Structures,” LPI Contribution No. 954, Lunar and Planetary Institute, Houston, 1998.

[3] PASSC, “Earth Impact Database,” 2013. http://www.passc.net/AboutUs/index.html

[4] U. G. Cordani, B. B. Brito Neves and B. B. Brito, "The 
Geologic Evolution of South America during the Archean and Early Proterozoic,” Revista Brasileira de Geociências, Vol. 21, No. 12, 1982, pp. 78-88.

[5] B. B. Brito, B. B. Brito Neves, U. G. Cordani and R. A. Thomaz Filho, "Influence of Basement Structures on the Evolution of the Major Sedimentary Basins of Brasil,” Journal Geodynamics, Vol. 14, No.1, 1984, pp. 495-510.

[6] F. F. M. Almeida, B. B. Brito Neves and C. D. R. Carneiro, "The Origin and Evolution of the South American Platform,” Earth-Science Reviews, Vol. 41, No. 50, 2000, pp. 77-111. doi:10.1016/S0012-8252(99)00072-0

[7] R. Kollert, A. Björnberg and A. Davino, "Estudos Preliminaries de Uma Depressão Circular na Região de Colônia: Santo Amaro, São Paulo,” Boletim da Sociedade Brasileira de Geologia, Vol. 3, No. 10, 1961, pp. 57-77.

[8] A. P. Crósta, "Estruturas de Impacto No Brasil: Uma Síntese do Conhecimento Atual,” 32nd Congresso Brasileiro de Geologia, Anais, Salvador, 1982, pp. 1372-1377.

[9] A. P. Crósta, "Impact Structures in Brasil,” In: J. Pohl, Ed., Research in Terrestrial Impact Structures, Braunschweig/Wiesbaden, Friedr. Wieweg and Son, 1987, pp. 30-38. doi:10.1007/978-3-663-01889-6_2

[10] C. Riccomini, B. Turcq, L. Martín and M. Z. Moreira, “The Colônia Astrobleme," International Symposium on Global Changes in South America during the Quaternary: Present and Future, Excursion Field Guide, São Paulo, 1989, p. 14.

[11] C. Riccomini, B. Turcq, L. Martín, M. Z. Moreira and M. L. Lorscheitter, “The Colônia Astrobleme,” Revista do Instituto Geológico, Vol. 12, No. 1, 1991, pp. 87-94.

[12] U. S. Motta and J.-M. Flexor, "Estudo Gravimétrico da Depressão Circular de Colônia, São Paulo, Brasil,” 2nd Congresso Internacional da Sociedade Brasileira de Geo-física, Anais, Salvador, 1991, pp. 140-142.

[13] W. C. B. Masero and S. L. Fontes, “Geoelectrical Studies of the Colônia Impact Structure, Santo Amaro, State of São Paulo-Brazil,” Revista Brasileira de Geofísica, Vol 10, No. 5, 1992, pp. 25-41.

[14] F. A. Neves, "Estudo da Depressão Circular de Colônia, SP, Pelo Método Sísmico,” Revista Brasileira de Geociências, Vol. 28, No. 1, 1998, pp. 3-10.

[15] C. Riccomini and B. J. Turcq, "The Colônia Crater, a Probable Impact Structure in Southeastern Brazil,” Meteoritics and Planetary Science, Vol. 39, No. 5208, 2004, p. A88.

[16] C. Riccomini, B. J. Turcq, M.-P. Ledru, L. G. Sant’Anna and J. A. Ferrari, "Cratera de Colônia, SP-Provável Astroblema Com Registros do Paleoclima Quaternário na Grande São Paulo,” 2005. http://www.unb.br/ig/sigep/sitio116/sitio116.pdf

[17] R. A. F Grieve and A. Therriault, “Observations at Terrestrial Impact Structures: Their Utility in Constraining Crater Formation," Meteoritics and Planetary Science, Vol. 39, No. 2, 2004, pp. 199-216. doi:10.1111/j.1945-5100.2004.tb00336.x

[18] C. Koeberl and B. Milkereit, "Continental Drilling and the Study of Impact Craters and Processes-An IDCP Perspective,” In: U. Harms, C. Koeberl and M. D. Zoback,
Eds., Continental Scientific Drilling, Springer, Heilderberg, 2007, pp. 95-161.

[19] J. K. Pati, K. Prakash and R. Kundu, "Terrestrial Impact Structures and Their Confirmation: Example from Dhala Structure, CENTRAL INDIA,” E-Journal Earth Science India, Vol. 2, No. 4, 2009, pp. 289-298.

[20] B. M. French, "Distribution of Shock-Metamorphic Features in the Sudbury Basin, Ontario, Canada,” Meteoritics, Vol. 4, 1969, pp. 173-174.

[21] D. Stöffler, "Deformation and Transformation of RockForming Minerals by Natural and Experimental Shock Processes: I. Behaviour of Minerals under Shock Compression,” Fortschritte der Mineralogie, Vol. 49, No. 1, 1972, pp. 50-113.

[22] D. Stöffler, "Deformation and Transformation of RockForming Minerals by Natural and Experimental Shock Processes: II. Physical Properties of Shocked Minerals," Fortschritte der Mineralogie, Vol. 51, No. 1-4, 1974, pp. 256-289.

[23] J. G. Spray, "Localized Shock- and Friction-Induced Melting in Response to Hypervelocity Impact," Geological Society of London, Special Publication, Vol. 140, No. 1, 1998, pp. 195-204.

[24] F. Langenhorst, "Shock Metamorphism of Some Minerals: Basic Introduction and Microstructural Observations," Bulletin of the Czech Geological Survey, Vol. 77, No. 4, 2002, pp. 265-282.

[25] B. M. French and C. Koeberl, "The Convincing Identification of Terrestrial Meteorite Impact Structures: What Works, What Doesn't, and Why," Earth-Science Reviews, Vol. 98, No. 3-4, 2010, pp. 123-170. doi:10.1016/j.earscirev.2009.10.009

[26] F. F. M. Almeida, G. Amaral, U. G. Cordani and K. Kawashita, "The Precambrian Evolution of the Southamerican Cratonic Margin South of Amazon River,” In: E. M. Nairn and F. G. Stheli, Eds., The Ocean Basins and Margins, Plenun, New York, 1973, pp. 411-446.

[27] J. M. V. Coutinho, "Carta Geológica da Região Metropolitana da Grande São Paulo,” Escala 1:100.000. São Paulo, EMPLASA, 1980, 2 folhas.

[28] Y. Hasui, C. D. R. Carneiro and A. M Coimbra,. "The Ribeira Folded Belt,” Revista Brasileira de Geociências, Vol. 5, No. 4, 1975, pp. 257-266.

[29] G. R. Sadowski, "Tectônica da Serra de Cubatão, SP,” PhD dissertation, Instituto de Geociências, Universidade de São Paulo, São Paulo, 1974.

[30] C. Riccomini, F. A. P. S. Neves and B. J. Turcq, “Astroblema de Colônia (São Paulo, Brasil): Estágio Atual de Conhecimento,” 37 Congresso Brasileiro de Geologia, São Paulo, Roteiros das Excursões, 1992, pp. 1-14.

[31] C. Riccomini, A. P. Crosta, R. L. Prado, M. -P. Ledru, B. J. Turcq, L. G. Sant'Anna, J. A. Ferrari and W. U. Reimold, “The Colônia Structure, São Paulo, Brazil,” Meteoritics \& Planetary Science, Vol. 46, No. 11, 2011, pp. 1630-1639. doi:10.1111/j.1945-5100.2011.01252.x

[32] D. Stöffler and R. A. F. Grieve, "Impactites, Chapter 2.11,” In: D. Fettes, and J. Desmons, Eds., Metamorphic Rocks: A Classification and Glossary of Terms, Recom- 
mendations of the International Union of Geological Sciences, Cambridge University Press, Cambridge, 2007, pp. 82-92, pp. 111-125 and pp. 126-242.

[33] S. W. Kieffer, "Shock Metamorphism of the Coconino Sandstone at Meteor Crater, Arizona,” Journal of Geophysical Research, Vol. 76, No. 23, 1971, pp. 5449-5473. doi:10.1029/JB076i023p05449

[34] F. Langenhorst and A. Deutsch, "Minerals in Terrestrial Impact Structures and Their Characteristic Features," In: A. S. Marfunin, Ed., Advanced Mineralogy, Vol. 3, Springer-Verlag, Berlin, 1998, pp. 95-119.

[35] L. Ferrière, C. Koeberl and W. U. Reimold, "Characterisation of Ballen Quartz and Cristobalite in Impact Breccias: New Observations and Constraints on Ballen Formation,” European Journal of Mineralogy, Vol. 21, No. 1, 2009, pp. 203-217. doi:10.1127/0935-1221/2009/0021-1898

[36] Sz. Nagi, A. Gucsik, Sz. Bérczi, N. Ninagagua, H. Nishido, A. Kereszturi, H. Hargitai and T. Okumura, "KFeldspar and Biotites Shock Indicator Minerals from Bosumtwi Impact Crater," Lunar and Planetary Science, Vol. 39, No. 1391, 2008, p. 1144.

[37] H. Schneider, "Shock-Induced Mechanical Dformation in Biotites from Crystalline Rocks of the Ries Crater (Southern Germany)," Contributions to Mineralogy and Petrology, Vol. 37, No. 1, 1972, pp. 75-85. doi:10.1007/BF00377308

[38] W. U. Reimold, H. Leroux and R. L. Gibson, "Shocked and Thermally Metamorphosed Zircon from the Vredefort Impact Structure, South Africa: A Transmission Electron Microscopic Study,” European Journal of Mineralogy, Vol. 14, No. 1, 2002, pp. 859-868. doi:10.1127/0935-1221/2002/0014-0859

[39] A. Wittmann, T. Kenkmann, R. T. Schmitt and D. Stoffler, "Shock-Metamorphosed Zircon in Terrestrial Impact Craters," Meteoritics and Planetary Science, Vol. 41, No. 3, 2006, pp. 433-454. doi:10.1111/j.1945-5100.2006.tb00472.x

[40] N. E. Timms, S. M. Reddy, D. Healy, A. A. Nemchin, M. L. Grange, R. T. Pidgeon and R. Hart, "Resolution of Impact-Related Microstructures in Lunar Zircon: A ShockDeformation Mechanism Map," Meteoritics and Planetary Science, Vol. 47, No. 1, 2012, pp. 120-141. doi:10.1111/j.1945-5100.2011.01316.X

[41] D. Stöffler, K. Keil and E. R. D. Scott, "Shock Metamorphism of Ordinary Chondrites," Geochemical and Cosmochemical Acta, Vol. 55, No. 12, 1991, pp. 3845-3867. doi:10.1016/0016-7037(91)90078-J

[42] D. Stöffler, "Progressive Metamorphism and Classification of Shocked and Brecciated Crystalline Rocks at Impact Craters,” Journal of Geophysical Research, Vol. 76,
No. 23, 1971, pp. 5541-5551. doi:10.1029/JB076i023p05541

[43] D. Söffler, "Glasses Formed by Hypervelocity Impact," Journal Non-Crystalline Solids, Vol. 67, No. 1-3, 1984, pp. 465-502. doi:10.1016/0022-3093(84)90171-6

[44] R. A. F. Grieve, L. Langenhorst and D. Stöffler, "Shock Metamorphism of Quartz in Nature and Experiment: II. Significance in Geosciences," Meteoritics and Planetary Science, Vol. 31, No. 1, 1996, pp. 6-35. doi:10.1111/j.1945-5100.1996.tb02049.x

[45] H. Leroux, W. U. Reimold, C. Koeberl, U. Hornemann and J.-C. Doukhan, "Experimental Shock Deformation in Zircon: A Transmission Electron Microscopic Study," Earth and Planetary Science Letters, Vol. 169, No. 3-4, 1999, pp. 291-301. doi:10.1016/S0012-821X(99)00082-5

[46] M.-P. Ledru, D.-D. Rousseau, F. W. J. Cruz, I. Karmann, C. Riccomini and L. Martin, "Paleoclimate Changes during the Last 100 ka from a Record in the Brazilian Atlantic Rainforest Region and Interhemispheric Comparison," Quaternary Research, Vol. 64, No. 3, 2005, pp. 444-450. doi:10.1016/j.yqres.2005.08.006

[47] M.-P. Ledru, P. Mourguiart and C. Riccomini, "Related Changes in Biodiversity, Insolation and Climate in the Atlantic Rainforest Since the Last Interglacial," Palaeogeography, Palaeoclimatology, Palaeoecology, Vol. 271, No. 3-4, 2009, pp. 140-152. doi:10.1016/j.palaeo.2008.10.008

[48] V. F. Velázquez, J. Hachiro, C. Riccomini, L. G. Sant’Anna and S. A. P. Godoy, "A Crater de Colônia Como Parque Temático e Georrecurso,” 43th Congresso Brasileiro de Geologia, Aracajú, 2006.

[49] V. F. Velázquez, J. B. Barros, C. Riccomini, J. Hachiro and L. G. Sant’Anna, “A Cratera de Colônia: Herança Geológica e Patrimônio Natural na Zona sul da Região Metropolitana de São Paulo,” 44th Congresso Brasileiro de Geologia, Curitiba, 2008.

[50] V. F. Velázquez, C. Riccomini, J. M. Azevedo Sobrinho, A. S. Rankin, A. M. E. Sallun, J. Hachiro and L. G. Sant'Anna, "Microscopic Evidence of Shock Metamorphism Effects in Detrital Minerals from the Colônia Crater Sediments, SP," 45th Congresso Brasileiro de Geologia, Belem, 2010.

[51] V. F. Velázquez, J. M. Azevedo Sobrinho, A. M. E. Sallun, W. F. Sallun, M. A. J. S. Pletsch and A. S. Rankin, "Mineralogia e Litogeoquímica dos Sedimentos Que Ocorrem na Parte Interna da Cratera de Colônia Com Base nas Amostras Provenientes da Sondagem P5," 46th Congresso Brasileiro de Geologia, Santos, 2012. 